\title{
Short-term propofol anaesthesia down-regulates clock genes expression in the master clock
}

\begin{abstract}
Nawfel Ben-Hamouda (10, ${ }^{\mathrm{a}, \mathrm{b}}$, Vincent-Joseph Poirel ${ }^{\mathrm{a}}$, Garance Dispersyn ${ }^{\mathrm{a}, \mathrm{c}}$, Paul Pévet $^{\mathrm{a}}$, Etienne Challet ${ }^{\mathrm{a}}$, and Laure Pain ${ }^{\mathrm{a}, \mathrm{d}}$

5 anstitut des neurosciences cellulaires et integratives, Neurobiology of Rhythms, CNRS (UPR3212), Université de Strasbourg, Strasbourg, France; ${ }^{b}$ Adult intensive Care Medicine and Burns, Centre Hospitalier Universitaire Vaudois, Lausanne, Switzerland; Institut de recherche biomedicale des armees, Bretigny-sur-Orge, France; dAnesthesiology, Hopitaux universitaires de Strasbourg, Strasbourg, France
\end{abstract}

ARTICLE HISTORY Received 20 April 2018; Revised 6 July 2018; Accepted 8 July 2018

\section{Introduction}

10 Circadian rhythmicity is of crucial relevance for anaesthesia, not only for chronopharmacological aspects, but also for the clinical management of patients (Dispersyn et al. 2009).

Mammalian physiology is endogenously rhyth-

15 mic on a daily basis, due to a network of circadian clocks that generate an internal cyclic timing. At the top of the circadian system is a master clock located in the suprachiasmatic nuclei $(\mathrm{SCN})$ of the hypothalamus. This structure provides timing 20 signals to many secondary clocks and oscillators in the brain and peripheral organs, thus controlling indirectly many circadian rhythms in behaviour (e.g., the sleep-wake cycle), physiology (e.g., hormonal secretion, like pineal melatonin or

25 adrenal glucocorticoids) (Kalsbeek et al. 2011) and sensitivity to drugs (e.g., anaesthetics) (Dispersyn et al. 2010). Furthermore, the SCN clock can be reset by environmental cues, allowing the phase-adjustment of internal rhythmicity 30 to the external cues.

Although the main environmental synchronizer (also called "Zeitgeber" or "time-giver") is ambient light, the SCN clock can also be reset by other, non-photic cues. The most common

35 non-photic factors are behavioural manipulations, although nutritional cues may also impact SCN function (Challet 2010). Period (Per)1 and Per2 are genes participating in the main feedback loop of the molecular clockwork and involved in 40 resetting of the SCN (Ko and Takahashi 2006).
More precisely, expression of both genes in nocturnal rodents' SCN is up-regulated by light exposure during nighttime (i.e., period of minimal daily expression) and down-regulated by behavioural activation during daytime (i.e., per- 45 iod of maximal daily expression) (Albrecht et al. 1997; Challet and Pévet 2003).

The chronobiotic impact of general anaesthetics (i.e., their effect on the circadian clock) is not fully characterized yet. Propofol is a widely used intravenous anaesthetic. On the one hand, general anaesthesia induced by propofol triggers phaseadvances of SCN-controlled circadian rhythms only at certain times of the day (late resting period and early active period (Dispersyn et al. 2009; Challet et al. 2007). Moreover, general anaesthesia induced by propofol has been associated with a subsequent reduction of Per 2 mRNA levels in the whole brain (Yoshida et al. 2009). On the other hand, inhalational anaesthesia with sevoflurane leads to a down-regulation of Per2 in the SCN, but its shifting effects of the sleep-wake cycle have not been clearly identified (Ohe et al. 2011). One critical point that remains to be characterized is the acute effects of propofol anaesthesia per se on the SCN molecular clockwork. For that purpose, anaesthesia has to be of short duration (to limit secondary effects, such as hypothermia), without concomitant surgery (to avoid confounding effects on the read-out parameters) and in the absence of 70 light (to avoid stimulating effects of light on clock gene expression). In this context, we studied Per1 
and Per2 expression in the SCN of rats exposed to constant darkness after a single-dose injection of

75 propofol (or vehicle) when the SCN clock is shifted by propofol (i.e., late afternoon in rats).

\section{Material and methods}

\section{Animals and housing conditions}

Adult, 2-months-old, male Long-Evans rats (Rattus

80 norvegicus) were obtained from Janvier ${ }^{\oplus}$ (Le GenestSt-Isle, France). The experiment was performed in accordance with the Principles of Laboratory Animal Care (NIH published 86-23, revised 1985) and the French laws (License $n^{\circ} 67-88$ to E.C.).

85 Animals were housed in Plexiglas cages ( $n=5$ per cage) at $23^{\circ} \mathrm{C}$ under a $12 \mathrm{~h}$ light $/ 12 \mathrm{~h}$ dark cycle (LD) for 2 weeks. Food and water were available ad libitum. On the day of the experiment, all rats were transferred to constant darkness by not allowing lights on in the

90 morning. Because previous studies (Dispersyn et al. 2009; Challet et al. 2007) showed that propofol administration at the end of the resting period leads to phase-advanced sleep-wake and body temperature rhythms, rats received a single-dose injection of pro95 pofol $1 \%(120 \mathrm{mg} / \mathrm{kg}, n=15)$ or vehicle (Intralipid ${ }^{\odot}$ $10 \%, n=15$ ) in late day (i.e., projected circadian time (CT) 10 , that is, $10 \mathrm{~h}$ after the expected time of lights on). Thereafter, rats were decapitated after $\mathrm{CO}_{2}$ killing in darkness $1 \mathrm{~h}, 2 \mathrm{~h}$ or $3 \mathrm{~h}$ after the treatment (i.e.,

100 projected CT11, CT12 or CT13; $n=5$ per time and treatment). Brains were quickly removed, frozen with $-30^{\circ} \mathrm{C}$ isopentane and stored at $-80^{\circ} \mathrm{C}$.

\section{Radioactive in situ hybridization}

Twenty- $\mu$ m brain coronal sections at the SCN level 105 were made on a cryostat, mounted in series on SuperFrost ${ }^{\oplus}$ Plus slides (VWR, USA) that were stored at $-20^{\circ} \mathrm{C}$. We analysed expression of Per 1 and Per 2 mRNA in the SCN. The $r$ Per 1 and $r$ Per 2 clones are a gift from Prof. H. Okamura (Graduate School of

110 Pharmaceutical Sciences, Kyoto University, Japan). The sense (to check specificity of the signal) and antisense cRNA riboprobes were transcribed in the presence of ${ }^{35} \mathrm{~S}$-UTP $(0.4625 \mathrm{Mbq} / \mu \mathrm{l}$, PerkinElmer, France) according to the manufacturer's protocol 115 (MAXIscript, Ambion, Austin, TX, USA).
Briefly, sections were postfixed in $4 \%$ phosphatebuffered paraformaldehyde for $15 \mathrm{~min}$, rinsed in $1 \times$ phosphate buffer saline (PBS) for $2 \mathrm{~min}$, and then acetylated for $10 \mathrm{~min}$ in $0.1 \mathrm{M}$ triethanolamine and acetic anhydride. After a $1 \times$ PBS rinse for $2 \mathrm{~min}$, sections were dehydrated in graded ethanol series and finally dried at room temperature (RT). Hybridization was carried out at $54^{\circ} \mathrm{C}$ overnight with riboprobe in a solution containing $100 \%$ deionized formamide, $4 \mathrm{~g}$ of sulfate dextran, 50× Denhardt's solution, $20 \times$ sodium citrate saline (SSC), $40 \mathrm{mg}$ salmon sperm DNA, $10 \mathrm{mg}$ transfer RNA, $1 \mathrm{M}$ dithiothreitol. After hybridization, the sections were washed for $5 \mathrm{~min}$ in $2 \times$ SSC before being treated with ribonuclease A (Sigma-Aldrich; $10 \mathrm{mg} /$ $\mathrm{ml}$ ) and a buffer solution for $30 \mathrm{~min}$ at $37^{\circ} \mathrm{C}$. The slides were then rinsed and stringency washes were carried out $(1 \times$ SSC for $5 \mathrm{~min}$ at RT, and $0.2 \times$ SSC for $30 \mathrm{~min}$ at $62^{\circ} \mathrm{C}$ ). Finally, the sections were dehydrated in a graded ethanol series and air-dried at RT. Slides were exposed with ${ }^{14} \mathrm{C}$ standards to an autoradiographic film (BioMax ${ }^{\circledast}$ MR, Kodak, Lyon, France) for 3 days. Analysis of the autoradiograms was performed using NIH-ImageJ software. Background was subtracted. For each probe and each animal, quantification was calculated and averaged on three sections of middle SCN for a given brain by subtracting the intensity of staining of background area (diameter: $200 \mu \mathrm{m}$ ) measured in the anterior hypothalamic area above the SCN from an area (diameter: $200 \mu \mathrm{m}$ ) measured in the left and right SCN.

\section{Statistical analysis}

Data are presented as mean \pm SEM. Data were analysed with two-way analyses of variance (ANOVA; 150 $\mathrm{IBM}^{\circledast}$ SPSS $^{\circledast}$ Statistics version 25, Chicago, USA). Bonferonni post hoc tests were used if main effects or interactions were found to be significant.

\section{Results}

- Expression of Per1 ( $n=27$, not 30 due to lost 155 sections)

We found a time (CT11, CT12, CT13; F $(2,27)=15.103 ; p<0.001)$ and a treatment effect (Propofol, Intralipid $; \mathrm{F}(1,27)=4.407 ; p=0.048$ ). 


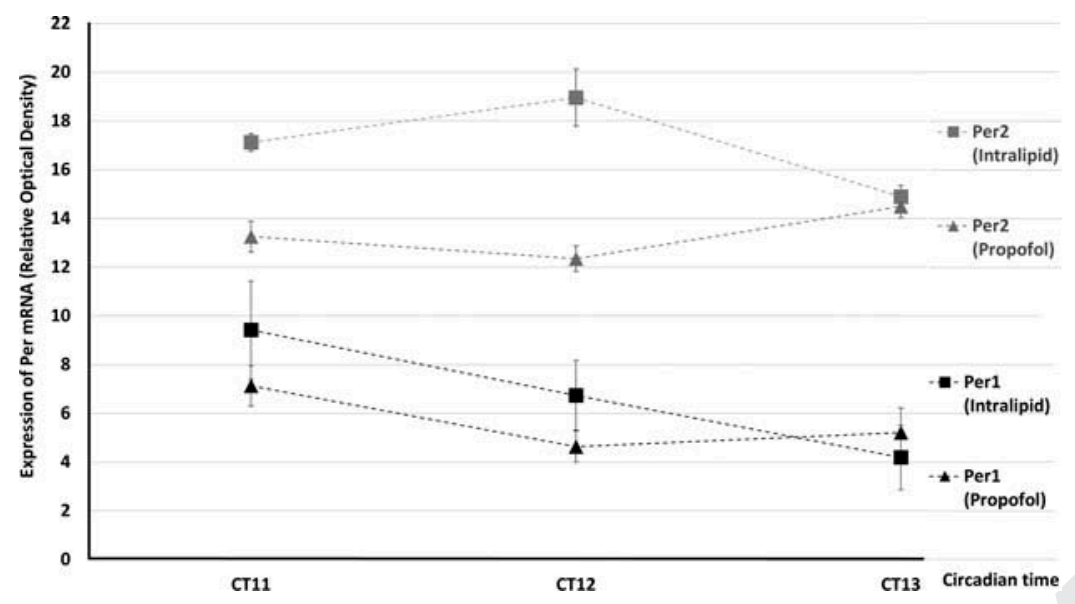

Figure 1.

The interaction between time/treatment was also sta-

160 tistically significant $(\mathrm{F}(2,27)=4.310 ; p=0.027)$. The post-hoc test showed only differences between CT11 versus CT12 $(p=0.005)$ and CT11 versus CT13 $(p<0.001)$ (Figure 1). Together, these results indicate that propofol anaesthesia induced a decrease in Per1

165 expression in the SCN at CT11 and CT12 when compared with vehicle group.

- Expression Per2 ( $n=26$, not 30 due to lost sections)

We observed a treatment effect (Propofol, Intralipid ${ }^{\oplus}$; $\mathrm{F}(1,26)=13.382 ; p=0.002)$, but no time effect

170 (CT11, CT12, CT13; $\mathrm{F}(2,26)=0.338 ; p=0.717)$ was detected. No difference between different time points was found with the post hoc test. Finally, the interaction between time/treatment was statistically significant $(\mathrm{F}(2,26)=3.535 ; p=0.048)$ (Figure 1).

175 Thus, the expression of Per 2 in the SCN is decreased at CT11 and CT12 after propofol anaesthesia.

\section{Discussion}

At behavioural level, propofol anaesthesia in rats produces phase-advances in the late (subjective)

180 daytime, an effect reminiscent of the chronobiotic consequences of classical non-photic cues (i.e., transient behavioural arousal associated with motor activity) studied in nocturnal mammals (Mrosovsky 1996; Challet and Pévet 2003) exogen-

185 ous melatonin (Pitrosky et al. 1999) and dark pulses in constant light (Dwyer and Rosenwasser 2000; Mendoza et al. 2004).
At molecular level, we show here for the first time that short-term anaesthesia induced by propofol leads to a transient down-regulation of Per 1 and Per2 expression in the SCN. These acute effects already known for behavioral arousal and dark pulses (Maywood et al. 1999; Mendoza et al. 2004) play a causal role in the resetting properties of non-photic cues (at least for Perl: see Hamada et al (Hamada et al. 2004). Of interest, even if treatment with exogenous melatonin can shift the SCN clock as propofol anaesthesia does, the initial molecular targets are not Per genes, but Rev-erb $\alpha$ and $\operatorname{Ror} \beta$ (Agez et al. 2007). Together, these data suggest that propofol anaesthesia shares activation of common transduction SCN pathways with classical non-photic cues and dark pulses, but not with pharmacological doses of melatonin.

\section{Per genes and anaesthesia}

Other studies have already found that general anaesthesia influences Per2 expression in the brain of rodents. They show a decrease in Per 2 expression after inhalational anaesthesia (sevoflurane) (Sakamoto et al. 2005; Kobayashi et al. 2007) 210 or after propofol anaesthesia (Yoshida et al. 2009). In these studies, gene expression was assessed in the whole brain and the authors have maintained anaesthesia for $2 \mathrm{~h}$ or more. Their animals were exposed to hypothermia and hypoxia, both being able to interact with circadian rhythmicity (Herzog and Huckfeldt 2003; Touitou et al. 2010). Ketamine, an intravenous anaesthetic acting as $\mathrm{N}$-methyl-d-aspartate (NMDA) receptors 
220 antagonist (Solt and Forman 2007) alters Per2 expression in an in vitro model (Bellet et al. 2011). Recently, a decrease in Per2 expression in SCN of rodents after 4-8 hours exposition to sevoflurane (Ohe et al. 2011; Kadota et al. 2012; Anzai 225 et al. 2013) or isoflurane anaesthesia (Xia et al. 2015) in subjective daytime is reported. Besides, Wang et al. show a suppression in Perl expression in the middle prefrontal cortex (mPFC) of rats (Wang et al. 2016). To our knowledge, the conse-

230 quence of general anaesthesia on Per1 expression in the SCN has not been studied yet.

\section{Cerebral targets of propofol}

To understand the molecular changes induced in the master clock by propofol, we need to investigate the

235 neurochemical mechanisms of general anaesthesia, especially the targets of propofol. Molecular studies have demonstrated that the $\triangle$-aminobutyric acid type A $\left(G_{A B A}\right)$ receptors are the main target of volatile anaesthetics (isoflurane, sevoflurane) and of propofol

240 (Solt and Forman 2007; Rudolph and Antkowiak 2004). $\mathrm{GABA}_{\mathrm{A}}$ receptors are the major inhibitory neurotransmitter-gated ion channels in the human brain (Solt and Forman 2007) and GABA is the principal neurotransmitter of the circadian system

245 (Moore and Speh 1993; Albers et al., 2017). More than $90 \%$ of SCN neurons contain GABA as a neurotransmitter and express both $\mathrm{GABA}_{\mathrm{A}}$ and $\mathrm{GABA}_{\mathrm{B}}$ receptors (Albers et al., 2017; Han et al. 2012). Propofol decreases neuronal excitability by enhan-

250 cing the activity of $\mathrm{GABA}_{\mathrm{A}}$ receptors. The hypnosis and immobility induced by propofol are mediated by $\mathrm{GABA}_{\mathrm{A}}$ receptors containing $\beta_{3}$ subunits, while sedation is linked to receptors containing $\beta_{2}$ subunits (Solt and Forman 2007). Propofol also acts through

255 other receptors like glycine receptors or calcium channels (Rudolph and Antkowiak 2004).

\section{GABAergic system in the $\mathrm{SCN}$ as a putative target of propofol anaesthesia}

The data mentioned above suggest that the propofol 260 action can be mediated by $\mathrm{GABA}_{\mathrm{A}}$ receptors in the $\mathrm{SCN}$. In vitro, GABA can induce phase-shifts in clock cells kept in culture and the daily treatment by GABA synchronizes cultured clock cells (Liu and Reppert 2000). In SCN explants of luciferase transgenic rats, the suppression of Per 2 expression 265 observed after sevoflurane application is blocked by the co-application of both $\mathrm{GABA}_{\mathrm{A}}$ and $\mathrm{GABA}_{\mathrm{B}}$ receptor antagonists, suggesting an GABergic mechanism (Matsuo et al. 2016). In vivo, the $\mathrm{GABA}_{\mathrm{A}}$ receptor activation by muscimol (a selective $\mathrm{GABA}_{\mathrm{A}}$ receptors agonist) during the mid-subjective day not only induces phase advances of locomotor activity in hamsters (Smith et al. 1989), but also suppresses Per1 mRNA and Per 2 mRNA expression in the SCN of both diurnal and nocturnal rodents (Ehlen et al. 2006; Novak et al. 2006). Yokota and al., report also phase advances in hamster locomotor activity and reduced expression of Per 1 and Per 2 in the SCN 1 and $2 \mathrm{~h}$ after injection of brotizolam (which is a $\mathrm{GABA}_{\mathrm{A}}$ receptor agonist belongs to benzodiazepines family) during mid-subjective daytime in hamsters (Yokota et al. 2000). The effects are quite comparable to those observed after propofol injection. However, the injection of muscimol (Smith et al. 1989) or brotizolam (Yokota et al. 2000) during the mid-subjective night leads to phase-delays of locomotor activity, while propofol anaesthesia has no longer any shifting effects at this time of day (Challet et al. 2007). In mutant mice with loss of function of voltage-gated $\mathrm{Na}+$ channel NaV1.1 (which is the primary voltage gate $\mathrm{Na}+$ channel in several classes of GABA interneurons), Han et al. demonstrated important disruption in the circadian master clock with longer circadian period, delayed activity onset and decreased circadian amplitude. 295 This impairment is related to reduction of GABAergic transmission (Han et al. 2012). In a recent abstract, the suppression of Per1 expression in the $\mathrm{mPFC}$ of rats following a propofol infusion is described. However, this result is not observed when propofol is co-administered with GABAzine (a GABAA receptor antagonist) (Wang et al. 2016).

\section{Other propofol targets?}

The molecular interaction of propofol with $\mathrm{GABA}_{\mathrm{A}}$ receptors is largely studied, but its action on glycine receptors is not fully clear. Recently, Nguyen et al. demonstrated that the glycine receptors partially contribute to propofol-induced hypnosis (Nguyen et al. 2009). An electrophysiological study on SCN cells revealed that glycine application induces phase advances during the subjective day and phase-delays 75

$$
\text { advances during the subjective day and phase-delays }
$$

$\sqrt{2}$


during the early subjective night (Mordel et al. 2011). The timing of these phase-shifts, however, is very different from those induced by in vivo injections of

315 propofol (Challet et al. 2007), suggesting that the chronobiotic effects of propofol are not mainly mediated via glycinergic signalling.

Another hypothesis for propofol action is a modulation of the gap junctions in the SCN. These junc-

320 tions made of connexins are responsible for the intercellular coupling between SCN cells (Aton and Herzog 2005). An ultrastructural study reported the immunocytochemical evidence that these neuronal gap junctions are composed of connexin36 (Rash

325 et al. 2007). Previously, Mantz and colleagues showed that propofol and other general anaesthetics differentially reduce permeability of gap junctions, at least in cultured astrocytes (Mantz et al. 1993). In rat SCN neurons cultured in vitro, the gap junction

330 communication is involved in interneuronal communication and the coupling state between neurons via $\mathrm{GABA}_{\mathrm{A}}$ receptor. The $\mathrm{GABA}_{\mathrm{A}}$ receptor agonist muscimol acts as a gap junction blocker (Shinohara et al. 2000). In the same way, connexin36-knockout

335 mice show dampened circadian activity rhythms and a delayed onset of activity during transition to constant darkness, as compared to wild-type mice (Long et al. 2005). Of note, these knockout mice show a greater sensitivity to anaesthetics, including propofol

340 (Jacobson et al. 2011). Together, these data suggest that the phase-shifts induced by propofol anaesthesia may be related to an uncoupling effect between SCN neurons mediated by $\mathrm{GABA}_{\mathrm{A}}$ receptors.

Some data suggest that circadian effects of anaes-

345 thetics result from the inhibition of the biding of the complex CLOCK:BMAL1 (Circadian Locomotor Output Cycles Kaput: Brain and Muscle Arnt-like 1 protein) via glycogen synthase kinase $3 \beta$ (GSK3 $\beta$ ) (Poulsen et al. 2018). In physiological conditions,

350 CLOCK:BMAL1 complex promotes Per genes transcription (Ko and Takahashi 2006). Ketamine, propofol anaesthesia or long-term sevoflurane exposure leads to (GSK3 $\beta$ ) inactivation (Poulsen et al. 2018). This effect has also been observed in the presence of

355 dizocilpine maleate (an NMDA receptor antagonist) (Hetman et al. 2000) suggesting an anti-NMDA mechanism of ketamine and sevoflurane, but another not yet elucidated mechanism for propofol.

Further studies are needed to better understand the underlying propofol anaesthesia and propose preventive treatments of the circadian disturbances, fatigue and sleep disorders reported by patients after general anaesthesia (Dispersyn et al. 2009).

\section{Acknowledgements}

We thank Dr. Dominique Sage-Ciocca for her help with animals management. The plasmids for synthesis of $r$ Per 1 and $r P e r 2$ were generously donated by Prof. H. Okamura (Graduate School of Pharmaceutical Sciences, Kyoto University, Kyoto, Japan).

\section{Funding}

This study was supported by the National Center for Scientific Research (CNRS), UPR3212 and the University of Strasbourg.

\section{Conflicts of interest}

The authors declare no conflicts of interest.

\section{ORCID}

Nawfel Ben-Hamouda (D) http://orcid.org/0000-0003-44285223

\section{References}

Agez L, Laurent V, Pévet P, Masson-Pévet M, Gauer F. 2007. 380 Melatonin affects nuclear orphan receptors mRNA in the rat suprachiasmatic nuclei. Neuroscience. 144:522-30.

Albers HE, Walton JC, Gamble KL, McNeill JK, Hummer DL. 2017. The dynamics of GABA signaling: Revelations from the circadian pacemaker in the suprachiasmatic nucleus. Front Neuroendocrinol. 44:35-82.

Albrecht U, Sun ZS, Eichele G, Lee CC. 1997. A differential response of two putative mammalian circadian regulators, mper1 and mper2, to light. Cell. 91:1055-64.

Anzai M, Iijima N, Higo S, Takumi K, Matsuo I, Mori K, Ohe Y, 390 Kadota K, Akimoto T, Sakamoto A, et al. 2013. Direct and specific effect of sevoflurane anesthesia on rat Per2 expression in the suprachiasmatic nucleus. PloS One. 8:e59454.

Aton SJ, Herzog ED. 2005. Come together, right...now: Synchronization of rhythms in a mammalian circadian clock. Neuron. 48:531-34.

Bellet MM, Vawter MP, Bunney BG, Bunney WE, SassoneCorsi P. 2011. Ketamine influences CLOCK:BMAL1 function leading to altered circadian gene expression. PloS One. 6:e23982.

Challet E. 2010. Interactions between light, mealtime and calorie restriction to control daily timing in mammals. J Comp Physiol [B]. 180:631-44. 
Challet E, Gourmelen S, Pevet P, Oberling P, Pain L. 2007. Reciprocal relationships between general (Propofol) anesthesia and circadian time in rats. Neuropsychopharmacology. 32:728-35.

Challet E, Pévet P. 2003. Interactions between photic and nonphotic stimuli to synchronize the master circadian clock in mammals. Front Biosci J Virtual Libr. 8:s246-57.

Dispersyn G, Chassard D, Pain L. 2010. [Biological rhythms for anaesthesia and intensive care]. Ann Fr Anesth Reanim. 29:470-77.

Dispersyn G, Touitou Y, Coste O, Jouffroy L, Lleu JC, Challet

415 E, Pain L. 2009. Desynchronization of daily rest-activity rhythm in the days following light propofol anesthesia for colonoscopy. Clin Pharmacol Ther. 85:51-55.

Dwyer SM, Rosenwasser AM. 2000. Effects of light intensity and restraint on dark-pulse-induced circadian phase shifting during subjective night in Syrian hamsters. J Biol Rhythms. 15:491-500.

Ehlen JC, Novak CM, Karom MC, Gamble KL, Paul KN, Albers HE. 2006. GABAA receptor activation suppresses Period 1 mRNA and Period 2 mRNA in the suprachiasmatic nucleus during the mid-subjective day. Eur J Neurosci. 23:3328-36.

Hamada T, Antle MC, Silver R. 2004. The role of Period1 in non-photic resetting of the hamster circadian pacemaker in the suprachiasmatic nucleus. Neurosci Lett. 362:87-90.

430 Han S, Yu FH, Schwartz MD, Linton JD, Bosma MM, Hurley JB, Catterall WA, De La Iglesia HO. 2012. Na(V)1.1 channels are critical for intercellular communication in the suprachiasmatic nucleus and for normal circadian rhythms. Proc Natl Acad Sci USA. 109:E368-77.

435 Herzog ED, Huckfeldt RM. 2003. Circadian entrainment to temperature, but not light, in the isolated suprachiasmatic nucleus. J Neurophysiol. 90:763-70.

Hetman M, Cavanaugh JE, Kimelman D, Xia Z. 2000. Role of glycogen synthase kinase-3beta in neuronal apoptosis induced by trophic withdrawal. J Neurosci Off J Soc Neurosci. 20:2567-74.

Jacobson GM, Voss LJ, Melin SM, Cursons RTM, Sleigh JW. 2011. The role of connexin 36 gap junctions in modulating the hypnotic effects of isoflurane and propofol in mice.

445 Anaesthesia. 66:361-67.

Kadota K, Iijima N, Ohe-Hayashi Y, Takumi K, Higo S, Sakamoto A, Ozawa H. 2012. Time-dependent repression of mPer2 expression in the suprachiasmatic nucleus by inhalation anesthesia with sevoflurane. Neurosci Lett. 528:153-58.

450 Kalsbeek A, Yi C-X, Cailotto C, La Fleur SE, Fliers E, Buijs RM. 2011. Mammalian clock output mechanisms. Essays Biochem. 49:137-51.

Ko CH, Takahashi JS. 2006. Molecular components of the mammalian circadian clock. Hum Mol Genet 15 Spec No.

\section{$455 \quad$ 2:R271-77.}

Kobayashi K, Takemori K, Sakamoto A. 2007. Circadian gene expression is suppressed during sevoflurane anesthesia and the suppression persists after awakening. Brain Res. 1185:1-7.

Liu C, Reppert SM. 2000. GABA synchronizes clock cells within the suprachiasmatic circadian clock. Neuron. 25:123-28.
Long MA, Jutras MJ, Connors BW, Burwell RD. 2005. Electrical synapses coordinate activity in the suprachiasmatic nucleus. Nat Neurosci. 8:61-66.

Mantz J, Cordier J, Giaume C. 1993. Effects of general anesthetics on intercellular communications mediated by gap junctions between astrocytes in primary culture. Anesthesiology. 78:892-901.

Matsuo I, Iijima N, Takumi K, Higo S, Aikawa S, Anzai M, Ishii H, Sakamoto A, Ozawa H. 2016. Characterization of sevoflurane effects on Per2 expression using ex vivo bioluminescence imaging of the suprachiasmatic nucleus in transgenic rats. Neurosci Res (N Y). 107:30-37.

Maywood ES, Mrosovsky N, Field MD, Hastings MH. 1999. Rapid down-regulation of mammalian period genes during behavioral resetting of the circadian clock. Proc Natl Acad Sci USA. 96:15211-16.

Mendoza JY, Dardente H, Escobar C, Pevet P, Challet E. 2004. Dark pulse resetting of the suprachiasmatic clock in Syrian hamsters: behavioral phase-shifts and clock gene expression. Neuroscience. 127:529-37.

Moore RY, Speh JC. 1993. GABA is the principal neurotransmitter of the circadian system. Neurosci Lett. 150:112-16.

Mordel J, Karnas D, Inyushkin A, Challet E, Pévet P, Meissl H. 2011. Activation of glycine receptor phase-shifts the circadian rhythm in neuronal activity in the mouse suprachiasmatic nucleus. J Physiol. 589:2287-300.

Mrosovsky N. 1996. Locomotor activity and non-photic influences on circadian clocks. Biol Rev Camb Philos Soc. 71:343-72.

Nguyen HT, Li K, daGraca RL, Delphin E, Xiong M, Ye JH. 2009. Behavior and cellular evidence for propofol-induced hypnosis involving brain glycine receptors. Anesthesiology. 110:326-32.

Novak CM, Ehlen JC, Paul KN, Fukuhara C, Albers HE. 2006. Light and GABA)(A) receptor activation alter period mRNA levels in the SCN of diurnal Nile grass rats. Eur J Neurosci. 24:2843-52.

Ohe Y, Iijima N, Kadota K, Sakamoto A, Ozawa H. 2011. The general anesthetic sevoflurane affects the expression of clock gene mPer2 accompanying the change of NAD+ level in the suprachiasmatic nucleus of mice. Neurosci Lett. 490:231-36.

Pitrosky B, Kirsch R, Malan A, Mocaer E, Pevet P. 1999. Organization of rat circadian rhythms during daily infusion of melatonin or S20098, a melatonin agonist. Am J Physiol. 277:R812-28.

Poulsen RC, Warman GR, Sleigh J, Ludin NM, Cheeseman JF. 2018. How does general anaesthesia affect the circadian clock? Sleep Med Rev. 37:35-44.

Rash JE, Olson CO, Pouliot WA, Davidson KGV, Yasumura T, Furman CS, Royer S, Kamasawa N, Nagy JI, Dudek FE. 2007. Connexin 36 vs. connexin32, "miniature" neuronal gap junctions, and limited electrotonic coupling in rodent suprachiasmatic nucleus. Neuroscience. 149:350-71.

Rudolph U, Antkowiak B. 2004. Molecular and neuronal 515 substrates for general anaesthetics. Nat Rev Neurosci. 5:709-20. 
Sakamoto A, Imai J-I, Nishikawa A, Honma R, Ito E, Yanagisawa Y, Kawamura M, Ogawa R, Watanabe S. 2005. Influence of inhalation anesthesia assessed by comprehensive gene expression profiling. Gene. 356:39-48.

Shinohara K, Hiruma H, Funabashi T, Kimura F. 2000. GABAergic modulation of gap junction communication in slice cultures of the rat suprachiasmatic nucleus. Neuroscience. 96:591-96.

Smith RD, Inouye S, Turek FW. 1989. Central administration of muscimol phase-shifts the mammalian circadian clock. J Comp Physiol [A]. 164:805-14.

Solt K, Forman SA. 2007. Correlating the clinical actions and molecular mechanisms of general anesthetics. Curr Opin Anaesthesiol. 20:300-06.

Touitou Y, Coste O, Dispersyn G, Pain L. 2010. Disruption of the circadian system by environmental factors: Effects of hypoxia, magnetic fields and general anesthetics agents.
Wang Y, Yuan C, Yu T, Cao S, Fu B. 2016. Abstract PR468: Propofol Alter the Expression of Circadian Genes By Gabaa Receptor in Medial Pfc of Rats. Anesth Analg. 123:162.

Xia T, Cui Y, Chu S, Ma Z, Gu X. 2015. Murine clock gene expression in the suprachiasmatic nuclei and peripheral blood mononuclear cells during the daily sleep-wake rhythm and after isoflurane anesthesia. Sleep Biol Rhythms. 13:357-65.

Yokota SI, Horikawa K, Akiyama M, Moriya T, Ebihara S, 545 Komuro G, Ohta T, Shibata S. 2000. Inhibitory action of brotizolam on circadian and light-induced per1 and per2 expression in the hamster suprachiasmatic nucleus. Br J Pharmacol. 131:1739-47.

Yoshida Y, Nakazato K, Takemori K, Kobayashi K, Sakamoto 550 A. 2009. The influences of propofol and dexmedetomidine on circadian gene expression in rat brain. Brain Res Bull. 79:441-44. 